\title{
Biogeochemical sequestration of carbon within phytoliths of wetland plants: A case study of Xixi wetland, China
}

\author{
LI ZiMin ${ }^{1}$, SONG ZhaoLiang ${ }^{1,2,3,4^{*}}$ \& JIANG PeiKun ${ }^{1,2}$ \\ ${ }^{1}$ School of Environment and Resources, Zhejiang Agricultural and Forestry University, Lin'an 311300, China; \\ ${ }^{2}$ Zhejiang Provincial Key Laboratory of Carbon Cycling in Forest Ecosystems and Carbon Sequestration, Zhejiang Agricultural and Forestry \\ University, Lin'an 311300, China; \\ ${ }^{3}$ Laboratories for Earth Surface Processes, Ministry of Education, Beijing 100871, China; \\ ${ }^{4}$ College of Urban and Environmental Sciences, Peking University, Beijing 100871, China
}

Received November 9, 2012; accepted January 30, 2013; published online April 10, 2013

\begin{abstract}
As an important long-term terrestrial carbon sequestration mechanism, biogeochemical sequestration of carbon within phytoliths may play a significant role in the global carbon cycle and climate change. The aim of this study is to explore the potential of carbon bio-sequestration within phytoliths produced by wetland plants. The results show that the occluded carbon content of phytoliths in wetland plants ranges from $0.49 \%$ to $3.97 \%$, with a CV (coefficient of variation) value of $810 \%$. The data also indicate that the phytolith-occluded carbon (PhytOC) content of biomass for wetland plants depends not only on the phytolith content of biomass, but also the efficiency of carbon occlusion within phytoliths during plant growth in herb-dominated fens. The fluxes of carbon bio-sequestration within phytoliths of herb-dominated fen plants range from 0.003 to $0.077 \mathrm{t} \mathrm{CO}_{2}$ equivalents t-e- $\mathrm{CO}_{2}$ $\mathrm{ha}^{-1} \mathrm{a}^{-1}$. In China, $0.04 \times 10^{6}$ to $1.05 \times 10^{6} \mathrm{t} \mathrm{CO}_{2}$ equivalents per year may be sequestrated in phytoliths of herbaceous-dominated fen plants. Globally, taking a fen area of $1.48 \times 10^{8}$ ha and the largest phytolith carbon biosequestration flux $\left(0.077 \mathrm{t}-\mathrm{e}-\mathrm{CO}_{2} \mathrm{ha}^{-1} \mathrm{a}^{-1}\right)$ for herb-dominated fen plants, about $1.14 \times 10^{7} \mathrm{t} \mathrm{CO}_{2}$ equivalents per year would have been sequestrated in phytoliths of fen plants. If other wetland plants have similar PhytOC production flux with herb-dominated fen plants $\left(0.077 \mathrm{t}_{-} \mathrm{e}-\mathrm{CO}_{2} \mathrm{ha}^{-1} \mathrm{a}^{-1}\right)$, about $4.39 \times 10^{7} \mathrm{t}-\mathrm{e}-\mathrm{CO}_{2} \mathrm{a}^{-1}$ may be sequestrated in the phytoliths of world wetland plants. The data indicate that the management of wetland ecosystems (e.g. selection of plant species) to maximize the production of PhytOC have the potential to bio-sequestrate considerable quantities of atmospheric $\mathrm{CO}_{2}$.
\end{abstract}

carbon sequestration, fen plants, wetland, phytolith occluded carbon (PhytOC), China

Citation: $\quad$ Li Z M, Song Z L, Jiang P K. Biogeochemical sequestration of carbon within phytoliths of wetland plants: A case study of Xixi wetland, China. Chin Sci Bull, 2013, 58: 2480-2487, doi: 10.1007/s11434-013-5785-3

The global concentration of atmospheric $\mathrm{CO}_{2}$ has increased significantly from $\sim 280$ to 391 ppmv since 1750 as a result of human activities such as fossil fuel combustion, deforestation, biomass burning and land use change [1]. As global increase of atmospheric $\mathrm{CO}_{2}$ concentration may cause dangerous climate change [2], various approaches that can securely reduce and sequestrate carbon emissions are being pursued, and among the most promising is the terrestrial biogeochemical carbon sequestration $[2,3]$.

One relatively stable form of organic carbon that is bio-

*Corresponding author (email: songzhaoliang78@163.com) geochemically sequestrated within the silica biomineralisation features of terrestrial plants and that can accumulate in soil after the decomposition of that vegetation is the phytolith occluded carbon (PhytOC) fraction [4]. The PhytOC is more stable and can sustain much longer than other organic carbon fractions in the soil because of its strong ability to resist decomposition [4-9]. For example, it has been reported that PhytOC in soil and sediments ranges in age from 0 to 8000 a BP [4]. One previous work found that PhytOC remained in soil for $13300 \pm 450$ a BP [10]. As an important part of terrestrial carbon, it can reach $82 \%$ of total carbon in some soil and sediments after 2000 years of litter leaf de- 
composition [4].

Phytoliths have great potential to sequestrate atmospheric $\mathrm{CO}_{2}$ through the formation of PhytOC [11-15], and play a crucial function in the long-term terrestrial carbon cycle [3, 4] and climate change [16-18]. The fluxes of millet, wheat and sugarcane for phytolith carbon bio-sequestration range up to 0.038 [14], 0.246 [13] and $0.36 \mathrm{t}-\mathrm{e}-\mathrm{CO}_{2} \mathrm{ha}^{-1} \mathrm{a}^{-1}$ [11], respectively. In particular, the flux of carbon occluded within phytoliths of bamboo ranges up to $0.709 \mathrm{t}-\mathrm{e}-\mathrm{CO}_{2}$ $\mathrm{ha}^{-1} \mathrm{a}^{-1}$, and current global bamboo forests (22 million ha) can securely sequestrate $1.56 \times 10^{7} \mathrm{t}$ of atmospheric $\mathrm{CO}_{2}$ per year. Researchers have suggested that if all potentially arable land (4.1 billion ha) is exploited to grow bamboo or other similar grass crops, the global potential of phytolith carbon bio-sequestration would approximately be 1.5 billion $\mathrm{t}-\mathrm{e}-\mathrm{CO}_{2} \mathrm{a}^{-1}$ equivalent to $11 \%$ of the current increase in atmospheric $\mathrm{CO}_{2}$ [12]. The data indicate that the management of plants with high PhytOC content to maximize biomass production could adequately improve the secure terrestrial carbon sequestration $[12,13]$. However, current estimation of global phytolith carbon bio-sequestration potential by Parr et al. [12] is based on a very small dataset. Under realistic conditions, much more work should be done before the strategy of PhytOC enhancement can be applied to sequestrate globally significant amounts of $\mathrm{CO}_{2}$.

The widespread wetland ecosystem with fast plant growth and high biomass is an important terrestrial carbon sink, and plays an important role in global carbon cycle [19-21] and global climate change [22-24]. As one of the important constituents of terrestrial ecosystems, wetlands store $15 \%$ of the total terrestrial carbon though it occupies only about $1 \%$ of the terrestrial surface [25]. Furthermore, the wetlands are mainly dominated by Poaceae, which are known to be proficient silica accumulators [26-29]. However, to our best knowledge, the potential of wetland phytoliths in the long-term biogeochemical sequestration of atmospheric $\mathrm{CO}_{2}$ has not been quantified globally and even regionally. The main purpose of this study is to examine the rates of silica accumulation and carbon bio-sequestration within the phytoliths of wetland plants.

\section{Materials and methods}

\subsection{Collection of wetland plant materials}

The Xixi wetland $\left(30^{\circ} 3^{\prime} 35^{\prime \prime}-30^{\circ} 21^{\prime} 28^{\prime \prime} \mathrm{N}, \quad 120^{\circ} 0^{\prime} 26^{\prime \prime}-\right.$ $\left.120^{\circ} 9^{\prime} 27^{\prime \prime} \mathrm{E}\right)$, a rare urban natural wetland with an area of 10.64 square kilometers, is located in the west part of Hangzhou, Zhejiang Province, China (Figure 1) [30,31]. It has rich ecological resources and simple natural landscapes densely crisscrossed with scattered ponds, lakes and swamps [32]. The site has a subtropical humid monsoon climate with an average annual precipitation of $1400 \mathrm{~mm}$, an annual mean temperature of $16.2^{\circ} \mathrm{C}$. The site is composed of paddy soil, boggy soil, and deposited soil [33].

The entire Xixi wetland is mainly dominated by herbaceous plants (Triarrhena sacchariflora, Phragmites australis, Cortaderia selloana, Arundo donax, Phyllostachys propinqua, Cyperus alternifolius, Arthraxon hispidus, etc.). Some trees (Salix spp, Melia azedarach, Broussonetia papyrifera, Morus, etc.) and shrubs (Clerodendrum trichotomum, Lonicera japonica, Rosa multiflora, etc.) are growing around the edges of the river base [34]. According to the classification system of Scott and Jones [35], the Xixi wetland is classified as fen [36-38].

In this study, three replicates of the 18 plant species belonging to different growth types (riparian plants, shallow water emergent plants and floating-leaf aquatics) (Figure 1 and Table 1) were randomly sampled at different sites of Xixi wetland to determine the variations of phytolith accumulation and to examine the global phytolith carbon biosequestration potential in wetland ecosystem. All collected plants were the herbaceous species that have large aboveground net primary productivity (ANPP) in Xixi wetland. They were collected at maturity in October, 2011, to ensure valid comparison and to obtain maximum flux of phytolith
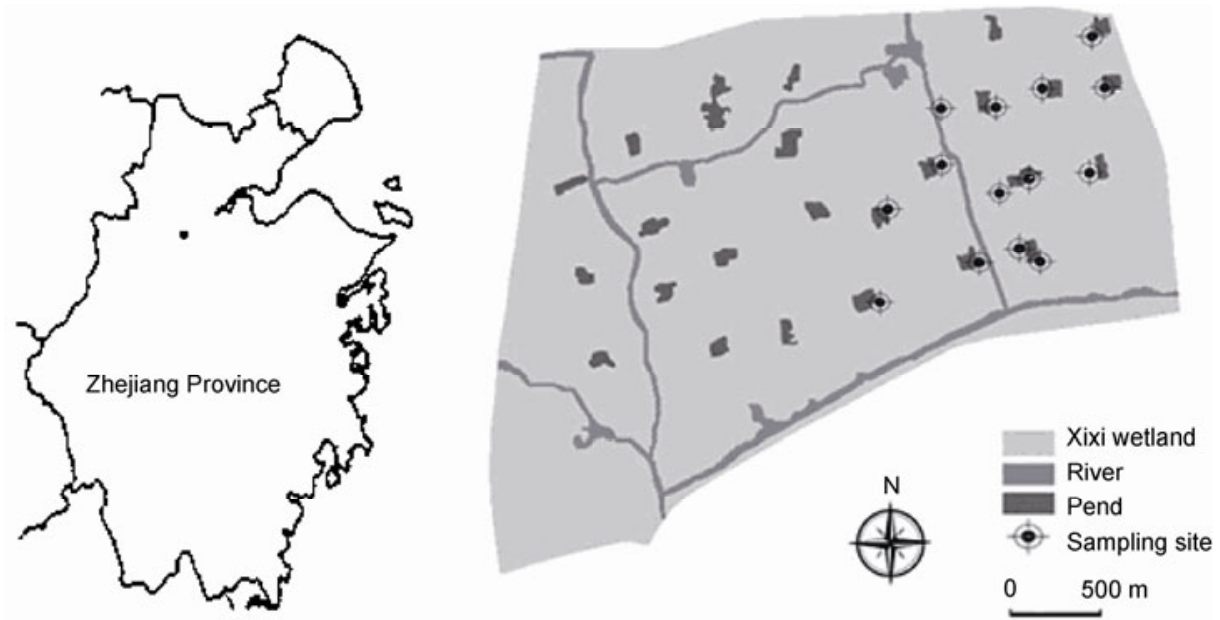

Figure 1 The location of Xixi wetland and sampling site. 
accumulation [39-41].

\subsection{Determination of Phytolith and PhytOC contents}

The root of the collected plants was discarded and the rest of the samples such as the stem, leaf, and spike were placed in an ultrasonic bath for $15 \mathrm{~min}$, rinsed three times with ultrapure water, dried at $75^{\circ} \mathrm{C}$ for $48 \mathrm{~h}$, and then cut into small pieces $(<5 \mathrm{~mm})$. The phytolith samples were extracted by microwave digestion procedures [42]. This process was followed by a Walkley-Black type digest to thoroughly remove extraneous organic materials in the samples $[12,43]$. The possible extraneous organic materials outside of the phytolith cells were examined with $0.8 \mathrm{~mol} / \mathrm{L}$ potassium dichromate. If the color of solution did not change within 5 min, it showed that the extraneous organic materials outside of the phytoliths were thoroughly removed. The phytoliths extracted were oven-dried at $75^{\circ} \mathrm{C}$ for $24 \mathrm{~h}$ in a centrifuge tube of known weight. The samples were allowed to cool and then weighed to obtain the phytolith quantities. The extracted phytolith samples were checked with an optical microscope (Olympus CX31, Japan) to ensure that all extraneous organic materials were thoroughly removed
[12-15,44,45]. Based on the methods of Kroger et al. [46], the dried phytolith samples were treated with $1 \mathrm{~mol} / \mathrm{L} \mathrm{HF}$ at $55^{\circ} \mathrm{C}$ for $60 \mathrm{~min}$ to dissolve phytolith-Si. The organic carbon released from phytoliths after HF treatment was dried at $45^{\circ} \mathrm{C}$ and determined for carbon content using the classical potassium dichromate method [47]. The organic carbon data was monitored with standard soil samples of GBW07405. The precision is better than $7 \%$.

\section{Results}

As Table 1 shows, the phytolith content of biomass has a significant variation $(1.01 \%-7.69 \%)$ among the 18 plant species. The phytolith contents of biomass for riparian plants $(2.32 \%-7.56 \%$, average $4.88 \%)$ and shallow-water emergent plants $(1.01 \%-7.69 \%$, average $4.14 \%)$ are higher than that $(1.88 \%-2.11 \%$, average $2.00 \%)$ for floating-leaf aquatics. The occluded carbon contents of phytoliths from riparian plants $(0.49 \%-3.94 \%$, average $1.59 \%)$ and shallowwater emergent plants $(1.10 \%-2.33 \%$, average $1.56 \%)$ are also higher than that $(0.91 \%-1.94 \%$, average $1.42 \%)$ from floating-leaf aquatics (Table 1). There are substantial

Table 1 The content and production of phytoliths and PhytOC together with biomass in 18 plants

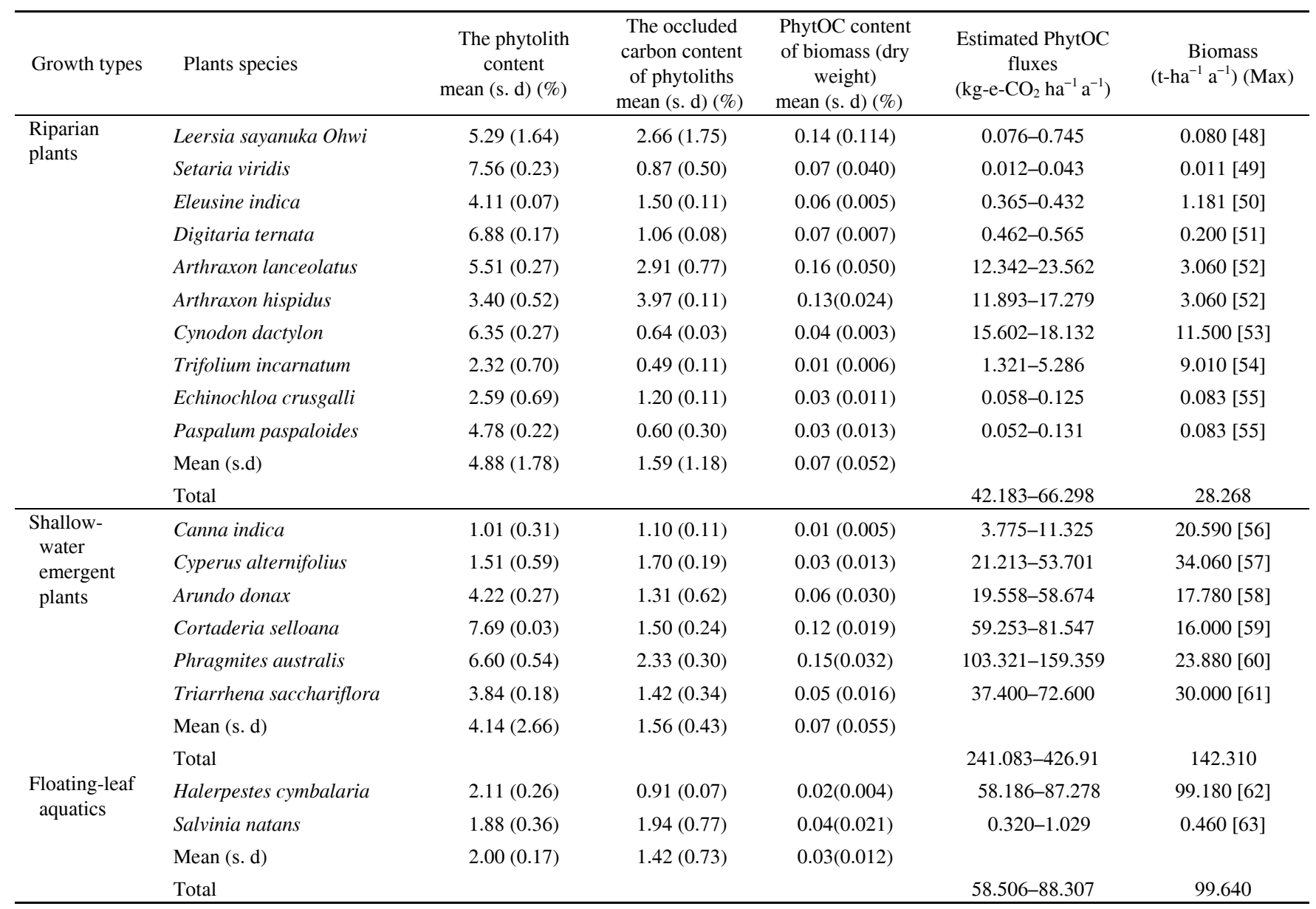


variations $(0.01 \%-0.16 \%)$ of PhytOC contents of biomass (dry weight) for the 18 plant species (Table 1). The PhytOC contents of biomass for riparian plants $(0.01 \%-0.16 \%$, average $0.07 \%)$ and shallow-water emergent plants $(0.01 \%-$ $0.16 \%$, average $0.07 \%)$ are much higher than that $(0.02 \%-$ $0.04 \%$, average $0.03 \%$ ) of floating-leaf aquatics (Table 1 ).

As Figure 2 shows, no obvious correlation $\left(R^{2}=0.0005\right.$, $P>0.05)$ exists between the phytolith content of biomass and the occluded carbon content of phytoliths in the 18 plant species. There is a weak positive correlation $\left(R^{2}=0.3477\right.$, $P<0.05)$ between the phytolith content of biomass and the PhytOC content of biomass among the 18 plant species (Figure 3). A strong positive correlation $\left(R^{2}=0.6066, P<\right.$ $0.01)$ exists between the occluded carbon content of phytoliths and the PhytOC content of biomass among the 18 plant species (Figure 4).

\section{Discussion}

\subsection{Mechanisms of carbon occlusion within phytoliths of wetland plants and its application}

Although the PhytOC content of biomass for different plants varies greatly, the factors controlling it remain to be found. Recent studies [11-14] indicate that the PhytOC

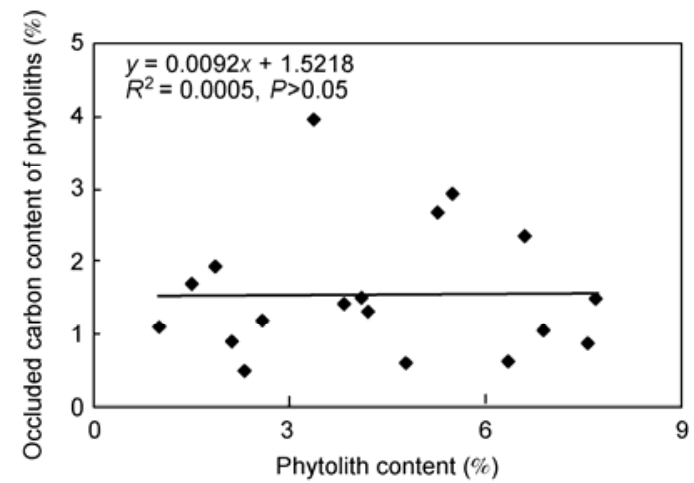

Figure 2 Correlation of the phytolith content of biomass for plants and occluded carbon content of phytoliths in the 18 plant species.

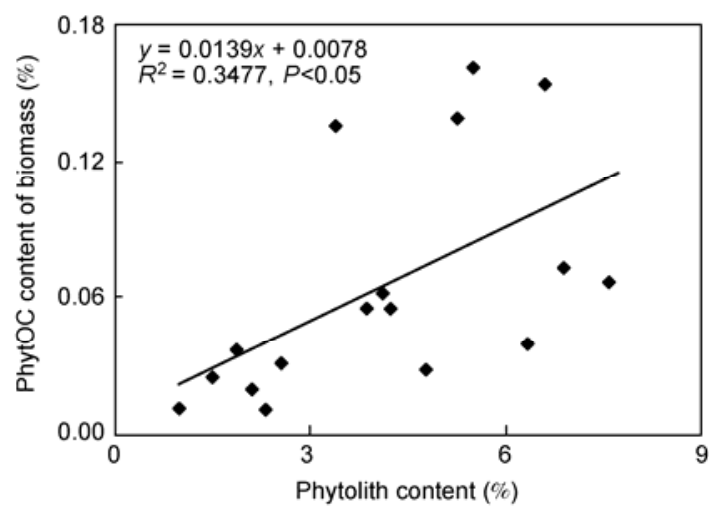

Figure 3 Correlation of the phytolith content of biomass and the PhytOC content of biomass for plants.

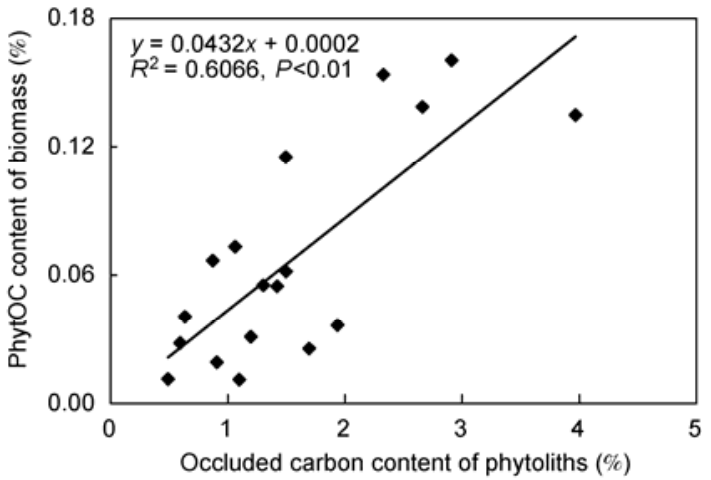

Figure 4 Correlation of occluded carbon content of phytoliths and the PhytOC content of biomass for plants.

contents of biomass for sugarcane, bamboo, wheat, and millet have no direct relationship with the actual content of silica (phytoliths) taken up by the plant, and mainly depend on the efficiency of the carbon occlusion within phytoliths during plant growth. However, the positive correlations between the phytolith content of biomass and PhytOC content of biomass $\left(R^{2}=0.3477, P<0.05\right)$ (Figure 3$)$, and between the occluded carbon content of phytoliths and the PhytOC content of biomass $\left(R^{2}=0.6066, P<0.01\right)$ among the 18 wetland plants (Figure 4 ) indicate that the PhytOC content in wetland plants might depend on both the content of phytoliths and the nature of silica occluding carbon within cells of the phytoliths during plant growth. Thus, all factors that influence the phytolith content of biomass and the efficiency of carbon sequestration within phytoliths may influence the PhytOC content of biomass for plants [15]. For example, factors including species, location, disease resistance, and nutrient requirements may play a crucial role in the accumulation of phytoliths during plant growth [15, 64,65]. The different shapes of phytoliths between different plants (e.g. between Poaceae and Leguminosae) may also cause differences in the occluded carbon content of phytoliths because of differences in specific surface area (Table 1) [15, $66,67]$. However, these indirect factors remain to be examined in further studies.

It is possible to enhance the PhytOC content of biomass for plants by selecting plant species of high-phytolith content and high-phytolith carbon occlusion efficiency $[12,13]$ and by regulating silicon nutrient supply. Although some plants have low phytolith carbon occlusion efficiency, it is still possible to improve the PhytOC content of biomass for plants by regulating silicon supply during plant growth. Some studies also demonstrate that the silica (phytoliths) content of biomass for plants can be effectively improved by adding silicon fertilizers [68-72], calcium-magnesium phosphate fertilizer [73], straws [74], and slag mucks [75]. Thus, it is possible to enhance the PhytOC content of biomass for plants by regulating silicon nutrient supply for some plants in artificial management ecosystems [15]. However, compared with regulation of silicon nutrient sup- 
ply, the selection of plant species with high phytolith content and high phytolith carbon occlusion efficiency has a better opportunity to improve the amount of bio-sequestrated carbon during land use and land-use change $[12,13,76]$. As Table 1 shows, the occluded carbon content of phytoliths among 18 plants species ranges from $0.49 \%$ to $3.97 \%$, a relative variation of $810 \%$. Therefore, these results show that the selection of species with high-phytolith content and high-occluded carbon content of phytoliths would lead to substantial enhancement of PhytOC content of biomass for plants [11-13]. This is also applicable for other plant species with significant variation of phytolith content and the occluded carbon content of phytoliths, such as sugarcane [11], bamboo [12] and wheat [13].

\subsection{Carbon sequestration potential within phytoliths of wetland plants}

The annual biomass production for each of the 18 plant species was not available for the study site in Xixi wetland. However, our estimated above-ground net primary productivity (ANPP) of some wetland communities is within the range of the published data of biomass (Table 1). Thus, the published ANPP of similar wetland communities was used in conjunction with the PhytOC content of biomass to estimate the potential of each plant PhytOC fluxes (Table 1). Because of the difference of the PhytOC content of biomass and ANPP among different plants, the potential plant PhytOC fluxes range from 0.012 to $159.359 \mathrm{~kg}-\mathrm{e}-\mathrm{CO}_{2}-\mathrm{ha}^{-1} \mathrm{a}^{-1}$ (Table 1). The mean contents of phytoliths and phytolith occluded carbon for floating-leaf aquatics are much less than that of shallow-water emergent plants. The total flux $\left(241.083-426.91 \mathrm{~kg}-\mathrm{e}-\mathrm{CO}_{2}-\mathrm{ha}^{-1} \mathrm{a}^{-1}\right)$ of PhytOC in shallow water emergent plants with the high-phytolith content, high-carbon occluded within phytoliths and high-biomass are significantly greater than that of riparian plants and floating-leaf aquatics. The flux (103.321-159.359 kg-e$\mathrm{CO}_{2}-\mathrm{ha}^{-1} \mathrm{a}^{-1}$ ) of PhytOC in Phragmites australis with higher content of phytolith and occluded carbon within phytoliths is much larger than that of other plants. So, it is significantly important to select a plant (e.g. Phragmites australis) with the high-phytolith content, high-carbon occluded within phytoliths and high-biomass grow to improve the total flux of PhytOC for plants in wetland ecosystems.

PhytOC sequestration flux of fen plant show that of herb-dominated fen ecosystem. According to the PhytOC sequestration flux of millet [14] and the global millet planting-area, the potential global total PhytOC sequestration rate of millet is estimated.

The published ANPP data of herb-dominated fen plants may be highly variable for different geographical locations and species [77-79]. For example, the estimated ANPP in mature herb-rich fen stands range from 1 to $29 \mathrm{t} \mathrm{ha}^{-1} \mathrm{a}^{-1}$ by Wheeler and Shaw [36]. Using the published ANPP data (1-29 $\left.\mathrm{t} \mathrm{ha}^{-1} \mathrm{a}^{-1}\right)$ of herb-dominated fen [36] and the mean PhytOC content of biomass for plants dry weight, the potential of PhytOC sequestration flux $\left(0.003-0.077 \mathrm{t}-\mathrm{e}-\mathrm{CO}_{2}\right.$ $\mathrm{ha}^{-1} \mathrm{a}^{-1}$ ) is quantified in herb-dominated fen ecosystem (Table 2). Compared with other studies (Table 2), the potential flux $\left(0.003-0.077 \mathrm{t}-\mathrm{e}-\mathrm{CO}_{2} \mathrm{ha}^{-1} \mathrm{a}^{-1}\right)$ of the phytolith carbon sequestration in this study is likely to be smaller than that of bamboo, wheat, sugarcane and rice [11-13,15]. The main causes are likely that the herb-dominated fen plant's ANPP or the occluded carbon content within phytoliths is less than that of bamboo, wheat, sugarcane and rice.

According to the published fen area $\left(1.37 \times 10^{7}\right.$ ha) by NBSC [80] and our studied PhytOC sequestration flux (0.003-0.077 t-e- $\left.\mathrm{CO}_{2} \mathrm{ha}^{-1} \mathrm{a}^{-1}\right)$ from herb-dominated fen plants (Table 2), it is estimated that the potential rates of $\mathrm{CO}_{2}$ occluded within phytoliths of herb-dominated fen plants vary from $0.04 \times 10^{6}$ to $1.05 \times 10^{6} \mathrm{t} \mathrm{CO}_{2}$ equivalents per year in China. Taking the world fen area $\left(1.48 \times 10^{8} \mathrm{ha}\right)$ [81] and the largest phytolith carbon bio-sequestration flux $\left(0.077 \mathrm{t}-\mathrm{e}-\mathrm{CO}_{2} \mathrm{ha}^{-1} \mathrm{a}^{-1}\right)$ of $\mathrm{CO}_{2}$ occlusion within phytoliths from herb-dominated fen plants, about $1.14 \times 10^{7} \mathrm{t} \mathrm{CO}_{2}$ equivalents per year would have been sequestrated in phytoliths of fen plants globally. As for the $5.7 \times 10^{8}$ ha of the world's wetlands [81], assuming a similar phytolith carbon bio-sequestration flux of $0.077 \mathrm{t}-\mathrm{e}-\mathrm{CO}_{2} \mathrm{ha}^{-1} \mathrm{a}^{-1}$, the global potential rate for phytoliths carbon sequestration is estimated to be $4.39 \times 10^{7} \mathrm{t}$-e $-\mathrm{CO}_{2} \mathrm{a}^{-1}$.

Although this study only chooses some Poaceae and other vegetation types to determine the variation of the PhytOC fluxes in herb-dominated fen ecosystems, the estimation of global potential $\mathrm{CO}_{2}$ sequestration rate $\left(4.39 \times 10^{7} \mathrm{t}\right)$ of phytoliths in wetland plants is much higher than that of bamboo

Table 2 Comparison of estimated PhytOC fluxes and global total PhytOC rate in different ecosystems

\begin{tabular}{lccc}
\hline World ecosystems & $\begin{array}{c}\text { PhytOC content of biomass } \\
(\text { dry weight })(\%)\end{array}$ & $\begin{array}{c}\text { PhytOC sequestration fluxes } \\
\left(\mathrm{t}-\mathrm{e}-\mathrm{CO}_{2} \mathrm{ha}^{-1} \mathrm{a}^{-1}\right)\end{array}$ & $\begin{array}{c}\text { Potential global total PhytOC } \\
\text { sequestration rates }\left(\mathrm{t}-\mathrm{e}-\mathrm{CO}_{2} \mathrm{a}^{-1}\right)\end{array}$ \\
\hline Fen & $0.01-0.25$ & $0.003-0.077$ & $\begin{array}{c}\text { References } \\
\text { this study }\end{array}$ \\
Rice & $0.04-0.28$ & $0.026-0.125$ & $1.14 \times 10^{7}$ \\
Bamboo & $0.24-0.52$ & $0.008-0.709$ & $1.94 \times 10^{7}$ \\
Sugarcane & $0.31-1.54$ & $0.12-0.36$ & $0.72 \times 10^{7}$ \\
Wheat & $0.06-0.60$ & $0.006-0.246$ & $5.3 \times 10^{7}$ \\
Millet & $0.04-0.27$ & $0.008-0.038$ & {$[11]$} \\
\hline
\end{tabular}


[12], sugarcane [11], millet [14] and rice [15] (Table 2). In fact, the PhytOC as a relatively stable organic carbon formed within many plants has considerable potential for the bio-sequestration of atmospheric $\mathrm{CO}_{2}$ [11-15]. As phytoliths can be conserved in significant quantities for thousands of years in some soils [82-84], the PhytOC may be considered as an important part of soil stable organic carbon and plays an important role in long-term carbon sequestration [4] and mitigation of global climate change [10-14]. However, this study is based on one particular type of herb-dominated fen but there are other types of wetlands with different vegetation compositions under different soil and climate conditions, and more studies need to be done to determine whether our conclusions can be extrapolated to other types of wetland ecosystems.

\section{Conclusions}

In this study, our results reveal that the occluded carbon content within phytoliths has substantial variation $(0.49 \%-$ $3.97 \%$ ) in the 18 wetland plants. The data also show that the PhytOC content of biomass for plants mainly depends on the efficiency of the carbon occluded within phytoliths during plant growth, and secondarily on the phytolith content. The potential PhytOC flux for fen plants ranges from 0.012 to $159.359 \mathrm{~kg}-\mathrm{e}-\mathrm{CO}_{2} \mathrm{ha}^{-1} \mathrm{a}^{-1}$. The selection of species with high-phytolith content and high-occluded carbon content of phytoliths for plants would lead to substantial enhancement of the PhytOC content of biomass for plants.

The potential PhytOC sequestration fluxes vary from 0.003 to $0.077 \mathrm{t}-\mathrm{e}-\mathrm{CO}_{2} \mathrm{ha}^{-1} \mathrm{a}^{-1}$ in herb-dominated fen ecosystems. In China, herb-dominated fen plants may sequestrate $0.04 \times 10^{6}$ to $1.05 \times 10^{6} \mathrm{t} \mathrm{CO}_{2}$ equivalents per year. Given the global fen area of $1.48 \times 10^{8}$ ha and the largest flux $\left(0.077 \mathrm{t}-\mathrm{e}-\mathrm{CO}_{2} \mathrm{ha}^{-1} \mathrm{a}^{-1}\right)$ of the $\mathrm{CO}_{2}$ occlusion within phytoliths of herb-dominated fen plants, we estimate that about $1.14 \times 10^{7} \mathrm{t} \mathrm{CO}_{2}$ equivalents per year would have been sequestrated in phytoliths of fen plants. Our study results reveal that the $5.7 \times 10^{8}$ ha of the world's wetlands, assuming a similar phytoliths carbon bio-sequestration flux $(0.077$ $\mathrm{t}-\mathrm{e}-\mathrm{CO}_{2} \mathrm{ha}^{-1} \mathrm{a}^{-1}$ ) of herb-dominated fen plants, about $4.39 \times$ $10^{7} \mathrm{t}-\mathrm{e}-\mathrm{CO}_{2} \mathrm{a}^{-1}$ may be sequestrated in phytoliths of wetland plants. However, more studies on the capacity of the PhytOC accumulation in other wetland plants are needed to quantify the global phytolith carbon bio-sequestration potential.

This work was supported by the National Natural Science Foundation of China (41103042), Zhejiang Provincial Key Science and Technology Innovation Team (2010R50030), Zhejiang Provincial Natural Science Foundation Program (Y5080110 and Z5080203), the Opening Project of State Key Laboratory of Environmental Geochemistry (SKLEG9011) and the Opening Project of Ministry of Education Laboratory for Earth Surface Processes, Peking University (201106).
1 Macías F, Arbestain M C. Soil carbon sequestration in a changing global environment. Mitig Adapt Strat Gl, 2010, 15: 511-529

2 Intergovernmental Panel on Climate Change (IPCC). Climate Change 2007: The Scientific Basis. Cambridge: Cambridge University Press, 2007

3 Oldenburg C M, Torn M S, DeAngelis K M, et al. Biologically Enhanced Carbon Sequestration: Research Needs and Opportunities. Report on the Energy Biosciences Institute Workshop on Biologically Enhanced Carbon Sequestration, 2008

4 Parr J F, Sullivan L A. Soil carbon sequestration in phytoliths. Soil Biol Biochem, 2005, 37: 117-124

5 Wilding L P, Brown R E, Holowaychuk N. Accessibility and properties of occluded carbon in biogenetic opal. Soil Sci, 1967, 103: 56-61

6 Wilding L P, Drees L R. Contributions of forest opal and associated crystalline phases to fine silt and clay fractions of soils. Clay Clay Miner, 1974, 22: 295-306

7 Mulholland S, Prior C. AMS radiocarbon dating of phytoliths. MASCA Res Pap Sci Archaeol, 1993, 10: 21-23

8 Stromberg C. Use phytolith assemblages to reconstruct the origin and spread of grass-dominated habitats in the great plains of North America during the late Eocene to early Miocene. Paleogeogr Paleoclimatol Paleoecol, 2004, 207: 239-275

9 Prasad V, Strömberg C, Alimohammadian H, et al. Dinosaur coprolites and the early evolution of grasses and grazers. Science, 2005, 310: 1177-1180

10 Wilding L P. Radiocarbon dating of biogenetic opal. Science, 1967, 156: 66-67

11 Parr J F, Sullivan L A, Quirk R. Sugarcane phytoliths: Encapsulation and sequestration of a long-lived carbon fraction. Sugar Tech, 2009, 11: 17-21

12 Parr J F, Sullivan L A, Chen B, et al. Carbon bio-sequestration within the phytoliths of economic bamboo species. Glob Change Biol, 2010, 16: 2661-2667

13 Parr J F, Sullivan L A. Phytolith occluded carbon and silica variability in wheat cultivars. Plant Soil, 2011, 342: 165-171

14 Zuo X X, Lü H Y. Carbon sequestration within millet phytoliths from dry-farming of crops in China. Chin Sci Bull, 2011, 56: 3451-3456

15 Li Z M, Song Z L, Parr J F, et al. Occluded C in rice phytoliths: Implications to biogeochemical carbon sequestration. Plant Soil, 2013, doi: 10.1007/s11104-013-1661-9

16 Gifford R. The global carbon cycle: A viewpoint on the missing sink. Funct Plant Biol, 1994, 21: 1-15

17 Falkowski P, Scholes R J, Boyle E, et al. The global carbon cycle: A test of our knowledge of earth as a system. Science, 2000, 290: 291-296

18 Kosten S, Roland F, Da Motta Marques D M L, et al. Climatedependent $\mathrm{CO}_{2}$ emissions from lakes. Glob Biogeochem Cycles, 2010, 24: GB2007

19 Martha A S, Brian C P, Enrique R, et al. Factors affecting spatial and temporal variability in material exchange between the Southern Everglades wetlands and Florida Bay (USA). Estuar Coast Shelf Sci, 2003, 57: 757-781

20 Sovik AK, Klove B. Emission of $\mathrm{N}_{2} \mathrm{O}$ and $\mathrm{CH}_{4}$ from a constructed wetland in southeastern Norway. Sci Total Environ, 2007, 380: 2837

21 Zhang F W, Liu A H, Li Y N, et al. $\mathrm{CO}_{2}$ flux in alpine wetland ecosystem on the Qinghai-Tibetan Plateau, China (in Chinese). Acta Ecol Sin, 2008, 28: 453-462

22 Clark J M, Lane S N, Chapman P J, et al. Export of dissolved organic carbon from an upland peatland during storm events: Implications for flux estimates. J Hydrol, 2007, 347: 438-447

23 McNamara N P, Plant T, Oakley S, et al. Gully hotspot contribution to landscape methane $\left(\mathrm{CH}_{4}\right)$ and carbon dioxide $\left(\mathrm{CO}_{2}\right)$ fluxes in a northern peatland. Sci Total Environ, 2008, 404: 354-360

24 Mariusz L, Milena O, Edward A D. Autogenic succession, land-use change, and climatic influences on the Holocene development of a kettle-hole mire in Northern Poland. Rev Palaeobot Palyno, 2008, 151: 21-40

25 Zhang Y, Li C, Trettin C C, Sun G, et al. Modelling soil carbon dy- 
namics of forested wetlands. Symposium 43. Carbon Balance of Peat lands sponsor. Inter Peat Soc, 1999

26 Drees L R, Wilding L P, Smeck N E, et al. Silica in soils: Quartz and disordered silica polymorphs. In: Dixon B, Weed S B, eds. Minerals in Soil Environments. Wisconsin: Soil Science Society America, 1989. 913-974

27 Ball T B, Gardner J S, Anderson N. Identifying inflorescence phytoliths from selected species of wheat (Triticummonoccum, $T$. dicoccon, T. dicoccoides, and T. aestivum and barley Hordeum vulgare and $H$. spontaneum). Am J Bot, 1999, 86: 1615-1623

28 Hodson M J, White P J, Mead A, et al. Phylogenetic variation in the silicon composition of plants. Ann Bot, 2005, 96: 1027-1046

29 Struyf E, Van Damme S, Gribsholt B, et al. Biogenic silica in freshwater marsh sediments and vegetation. Mar Ecol-Prog Ser, 2005, 303: 51-60

30 Chen Q, Wu Q J. Landscape pattern change and its driving forces in Xixi National Wetland Park since 1993 (in Chinese). Chin J Appl Ecol, 2006, 17: 1677-1682

31 Gao Y L. The practices and improvements of the Xixi National Wetland Park Model, Hangzhou (in Chinese). Wetland Sci Manage, 2006, 2: 55-59

$32 \mathrm{Lu} \mathrm{Y,} \mathrm{Chen} \mathrm{K} \mathrm{L.} \mathrm{Analysis} \mathrm{of} \mathrm{several} \mathrm{cases} \mathrm{of} \mathrm{wetland} \mathrm{protection} \mathrm{and}$ use at home and abroad and their inspiration for eco-tour of the Jinhu National Urban Wetland Park in Zhejing Province (in Chinese). Wetland Sci, 2006, 4: 268-273

33 Shao X X, Wu M, Jiang K Y. Distribution and ecological risk assessment of heavy metal elements in soil of Xixi wetland (in Chinese). Wetland Sci, 2007, 5: 254-259

34 Shen Q, Liu K, Li S Y, et al. Relationships of plant composition, water level and solar radiation in Xixi wetland, Hangzhou, China (in Chinese). J Plant Ecol (Chin Version), 2008, 32: 114-122

35 Scott D A, Jones T A. Classification and inventory of wetlands: A global overview. Plant Ecol, 1995, 118: 3-16

36 Wheeler B D, Shaw S C. Above-groud crop mass and species richness of the principal types of herbaceous rich-fen vegetation of lowland England and Wales. J Ecol, 1991, 79: 285-301

37 Charlton D L, Hilts S. Quantitative evaluation of fen ecosystems on the Bruce Peninsula. In: Bardecki M J, Patterson N, eds. Ontario Wetlands: Inertia or Momentum. Proceedings of Conference, Ryerson Polytechnical Institute, Toronto, Oct 21-22, 1988. Toronto, ON: Federation of Ontario Naturalists, 1989

38 Keddy P A. Wetland Ecology: Principles and Conservation. 2nd ed. Cambridge: Cambridge University Press, 2010

39 Large E C. Growth stages in cereals: Illustration of the Feeke'sscale. Plant Pathol, 1954, 3: 128-129

40 Norris A R, Hackney C T. Silica content of a Mesohaline Tidal Marsh in North Carolina. Estuar Coast Shelf Sci, 1999, 49: 597-605

41 Motomura H, Mita N, Susuki M. Silica accumulationin long-lived leaves of sasa veitchii (Carriere) rehder (Poaceae-Bambusoideae). Ann Bot-London, 2002, 90: 149-152

42 Parr J F, Dolic V, Lancaster G, et al. A microwave digestion method for the extraction of phytoliths from herbarium specimens. Rev Palaeobot Palyno, 2001, 116: 203-212

43 Walkley A, Black I A. An examination of the Degtjareff method for determining soil organic matter, and a proposed modification of the chromic acid titration method. Soil Sci, 1934, 37: 29-38

44 World Health Organization. Quality control methods for medicinal plant materials. Office of Publications, World Health Organisation, Geneva, 1998, 16

45 Murphy D B. Fundamentals of Light Microscopy and Electronic Imaging. New York: John Wiley \& Sons, Inc., 2002, 122

46 Kroger N, Lorenz S, Brunner E, et al. Self-assembly of highly phosphorylated silaffins and their function in biosilica morphogenesis. Science, 2002, 298: 584-586

47 Lu R K. Methods for Soil and Agrochemical Analysis. Beijing: China Agriculture Press, 2000

48 Chen X, Xia Y P, Li Q, et al. Study on the changes of aquatic vegetation and its biomass in Caohai (in Chinese). Caohai Nat Nat Res Protect Sci Res Guizhou, China, 2012 (http://www.caohaibhq.com/
operation.asp?ID=51)

49 He Y H, Zhao H L, Liu X P, et al. Growth characteristics and biomass allocation of Setaria viridis on different types of sandy land (in Chinese). Chin J Ecol, 2008, 27: 504-508

$50 \mathrm{Yu}$ M M. Studies on the population and the biomass changes of the main weeds in Zoysia Lawns of Hefei (in Chinese). Dissertation for the Master's Degree. Hefei: Anhui Agricultural University, 2008. 10-16

51 Tang $\mathrm{J} \mathrm{W}$, Zhang $\mathrm{J} \mathrm{H}$, Song Q S, et al. Biomass and net primary productivity of artificial tropical rainforest in Xishuangbanna (in Chinese). Chin J Appl Ecol, 2003, 14: 1-6

52 Zhang X L. Elimination effects of riparian vegetation buffer zones on surface water nitrogen and phosphorus in Yongting River of China (in Chinese). Dissertation for the Master's Degree. Beijing: Beijing Normal University, 2009. 12-14

53 Gill A S, Tang X C. Bermudagrass. India Farming, 1983

54 Pu C L, Zhou S R, Gang Y M, et al. Study on biomass and structuree of several cultivated legumes-concurrent analysis of planting density of landino white clover (in Chinese). J Sichuan Grassland, 1997, 2: $11-18$

55 Pan X J, Guo W, Sun B, et al. Effects of intra-specific competiton on biomass allocation of Echinochloa crusglli (in Chinese). J Henan Agric Sci, 2011, 40: 86-89

56 Li J N, Hu Y L,Wu X F, et al. Nitrogen and phosphours removal capacity of plant species in contructed wetlands for treating municipal wastewater (in Chinese). Environ Pollut Control, 2007, 29: 506-509

57 Liao X D, Luo S M, Wu Y B, et al. Comparison of nutrient removal ability between Cyperus alternifolius and Vetiveria zizanioides in construcred wetlands (in Chinese). Chin J Appl Ecol, 2005, 16: 156160

58 Xue P, Wang X P, Li X Q. Biomass dynamice of Aundp donax Linn. Growing on the Purple Shale areas in Hengyang, Hunan Province (in Chinese). J Central South Forestry Univ, 2006, 26: 12-14

59 Chen Q X, Zheng J, Jin C, et al. Nirtogen and phosphorus uptake of 18 aquatic plant species in Sanyang Wetland (in Chinese). Acta Agric Univ, 2008, 30: 438-442

60 Wu T G, Wu M, Yu M K, et al. Dynamics of biomass and N, P storage of Phragmites australis in Hangzhou Bay Wetlands (in Chinese). Chin Environ Sci, 2010, 30: 1408-1412

61 Huang J, Chen B J, Su Y S, et al. Progress in the development and utilization of Miscanthus Sacchariflorus (Maxim.) Nakai (in Chinese). Beijing Agric, 2011, 33: 183-184

62 Da L J, Chen M. Heavy metal content in different parts of Eichhornia Grassipes and adsorption of its root system (in Chinese). Shanghai Environ Sci, 2003, 22: 765-767

63 Li F, Xie Y H, Yang G, et al. Preliminary survey on aquatic vegetations in Baiyangdian Lake (in Chinese). Chin J Appl Ecol, 2008, 19: 1597-1603

64 Ma J F, Tamai K, Ichii M, et al. A rice mutant defective in active $\mathrm{Si}$ uptake. Plant Physiol, 2002, 130: 2111-2117

65 Ding T P, Ma G. R, Shui M X, et al. Silicon isotope study on rice plants from Zhejiang Province, China. Chem Geol, 2005, 218: 41-50

66 Bartoli F, Wilding L P. Dissolution of biogenic opal as a function of its physical and chemical properties. Soil Sci Soc Am J, 1980, 44: 873-878

67 Bartoli F. Crystallochemistry and surface properties of biogenic opal. J Soil Sci, 1985, 36: 335-350

68 Matichenkov V, Calvert D. Silicon fertilizers for citrus in Florida. Proc Fla State Hor Soc, 1999, 112: 5-8

69 Alvarez J, Datnoff L E. The economic potential of silicon for integrated management and sustainable rice production. Crop Prot, 2001, 20: $43-48$

70 Ma J F, Takahashi E. Soil, Fertilizer, and Plant Silicon Research in Japan. Amsterdam: Elsevier Science, 2002

71 Liang Y, Hua H, Zhu Y G, et al. Importance of plant species and external silicon concentration to active silicon uptake and transport. New Phytol, 2006, 176: 63-72

72 Mecfel J, Hinke S, Goedel W A, et al. Effect of silicon fertilizers on silicon accumulation in wheat. J Plant Nutr Soil Sci, 2007, 170: 769772 
73 Chen J G, Zhang Y Z, Zeng X B, et al. Effect of a long-term various fertilization on exchangeable $\mathrm{Ca}$ and $\mathrm{Mg}$, and available $\mathrm{S}$ and $\mathrm{Si}$ contents in paddy soils (in Chinese). Ecol Environ, 2008, 17: 2064-2067

74 Bao S D, Yang X R, Li X Q, et al. The effect of wheat yields on silicon nutrition and the zinc silicon fertilizer in calcareous soils (in Chinese). Soil, 1996, 6: 311-315

75 Zhang Y L, Yu L, Liu M D, et al. Silicon liberation characteristics of soil and its effect factors after applying slag mucks (in Chinese). Chin J Soil Sci, 2008, 39: 722-725

76 Intergovernmental Panel on Climate Change. Land Use, Land-Use Change and Forestry. Cambridge: Cambridge University Press, 2000

77 Bartsch I, Moore T R. Preliminary investigation of primary production and decomposition in four peatlands near Schefferville, Quebec. Can J Bot, 1985, 63: 1241-1248

78 Vitt D H, Halsey L A, Campbell C, et al. Spatial patterning of net primary production in wetlands of continental western Canada. Eco- science, 2001, 8: 499-505

79 Vitt D H, Wieder R K, Scott K D, et al. Decomposition and peat accumlation in rich fens of Boreal Alberta, Canada. Ecosystems, 2009, 12: $360-373$

80 National Bureau of Statistics of China. Area of Wetlands by Region. Beijing: China Statistics Press, 2011

81 World Energy Council. Survey of Energy Resources 2007. Retrieved 2008-08-11

82 Rosen A. Identifying ancient irrigation: A new method using opaline phytoliths from Emmer wheat. J Archaeol Sci, 1994, 21: 125-132

83 Zheng Y, Matsui A, Fujiwara H. Phytoliths of rice detected in the Neolithic sites in the valley of the Taihu Lake in China. Environ Archaeol, 2003, 8: 177-184

84 Cao Z H, Ding J L, Hu Z Y, et al. Ancient paddy soils from the Neolithic age in China's Yangtze River Delta. Naturwissenschaften, 2006, 93: $232-236$

Open Access This article is distributed under the terms of the Creative Commons Attribution License which permits any use, distribution, and reproduction in any medium, provided the original author(s) and source are credited. 